\title{
Preparing the Staff of Obafemi Awolowo University Ile-Ife to Appreciate and Use Information and Communication Technology for Solving Work Place Problems and Managing Change \\ Sofowora Olaniyi Alaba (PhD)
}

\begin{abstract}
This paper examined the various efforts the management and administration of Obafemi Awolowo University, Ile-Ife made to prepare and encourage its staff and students to appreciate and use ICT for solving work place problems and to manage change. It was also designed to investigate the extent to which accelerated computer/internet usage, job type; age and sex have affected the attitude of O.A.U Staff towards computer and Internet.

The study adopted the survey research design. Samples of 600 staff were selected through stratified sampling techniques. The result obtained showed that 94\% of the staff of OAU use computer. Also academic staff (49.2\%) used computer and Internet more than any other categories of staff. Not only this, female staff (58\%) used computer more than their male staff (42\%). In addition age is a correlate of ICT usage. Staffs between ages 25 and 40 are usually more favorably disposed to using ICT than staff that is above 40 years. $\left(\chi_{c}^{2}=15.67\right)$.

Keywords: ICT, Internet, Electronic mail, Disposition, Correlate, Management, Administration, Change
\end{abstract}




\section{Background}

Computers play an increasing role in modern society by allowing people to communicate and be connected. Many rely on computers for recreational, political, personal, educational and business affairs. The creation and widespread application of database tools has been one of the major reasons for the usage of computer technology. The information revolution that resulted as a result of computer usage has greatly affected education, social interaction, administration, recreation, security, business and commerce.

Obafemi Awolowo University (O.A.U) Ile-Ife is not left out of the revolution. The introduction and application of Information and Communication Technology (ICT) in O.A.U Ile-Ife recently have helped to create more efficient, less costly and higher quality service delivery and management. Within the last few years of introduction and implementation, there has been a tremendous impart on teaching, researches and on the entire University structure. Although the students and staff were provided computers and internet services but the available services provided by the University were under utilized. Several efforts have been made by the University Management to encourage both staff and students to acquire skills in computer and ICT. Computer loans were also provided for academic lecturers to help them acquire computers of their own, training facilities were also provided for all categories of staff. All the Departments in the University were given computers for administration and processing of results. Not only this, in order to further encourage the staff to use computer, the University mandated all the administrative and secretariat staff to acquire computer literacy. Apart from subsidizing the training fees, Internet facilities were provided in the University. In fact 
O.A.U. Ile-Ife was the first University in Nigeria to be connected to the Internet; it is also the best and foremost ICT University in the country. In order to encourage the University Community to use the Internet, the e-mail service registration fee was reduced to $\# 500.00$ monthly. It was later increased to \#1,500 in year 2004. In spite of all these efforts made to encourage the staff and students to appreciate ICT and computer, many of them still did not show interest in the use of these facilities. Many regarded the task of acquiring skills in computer a nightmare which reflected in their reluctance to acquire skill in it and to explore how they could use it to improve their life style and performance. The situation is worrisome because majority of the staff are yet to change their attitudes toward computer.

There had been several studies on the relationship between access to computer and interest (Senior Net 1998, Morell, Mayhorn and Benneth 2000 Adler 2002, Senior Net 2002a, 2002b, Morris and Deollos, 2004; China Daily News 2004). Also White et-al (2002) found out that access to Internet and e-mail can produce positive impart on the people. There are other descriptive studies on attitude to computer. One of the results relevant to this study is that the greater the experience with computer the more positive attitude about it. (Czaja and Sharit 1998, Keischner and Chelsvig Hart 1984, Krauss and Hoyer 1984). The problem with O.A.U staff is that in spite of the training facilities, exposure, provision of computers and internet services, the staffs are not yet favorably disposed to using it. This has implication for further development. It is being envisaged that by Harmattan Semester, 2006/2007 session, registration of courses will be strictly on-line. Base one the problem identified the researcher intends to investigate the extent to which accelerated computer usage, internet facilities, job 
type, age and sex have affected our attitudes toward computer. In order to achieve this, the following research questions were asked.

\section{Research Questions}

(i) To what extent are the Obafemi Awolowo University staffs computer literate?

(ii) What effect does the various efforts and policies of the University at encouraging the use of computer have on the staff?

(iii) Does age have any relationship with attitude toward computer?

(iv) Does job type affects our attitude towards computer and its usage?

(v) How did the staff react to the University policy that all administrative, secretariat and academic staff should be computer literate?

(vi) Does the various workshops and computer training promote changes in attitudes toward computer?

\section{Review of Related Literature}

The Internet as we know it today is a result of collaborated efforts of different researchers. This effort began in September 1969. It was sponsored by the Defense Advanced Project Agency (DRAPA), a division within the United State Department of Defense. Emanating from the research effort was the development of an "ARPA" net. The Defense Department and the Universities used this net. Not quite later, it became apparent that the "ARPA" net being used then was inadequate in a Wide Area Networks (WANS). Thus another research effort was put in place in 1973 to develop a suite of protocols for use. The outcome of the new research effort is what is known as (IP) Internet Protocol and 
Transmission Control Protocol (TCP). Internet can therefore be described as concatenation of security networks and several others. It is sometimes called Catanet or Internet just as the telephone enables you to talk to someone far from you, so also the Internet enables you to sit by your computer and exchange information with other computer users that are linked to the Internet at any place in the world. It allows information to flow through many interconnected computer networks within minutes. Over the years, Internet has since acquired such net name as; The Net, World Wide Web (WWW) and Information Super high way, from the above, one can define internet as the interconnection of Wide Area Networks (WANs) for the purpose of disseminating information by making use of the website.

\section{Transaction on the Internet}

Available transactions on the Internet include:

(i) Instant message,

(ii) Electronic mailing (e-mail),

(iii) Virtual learning environment,

(iv) Shopping (e-commerce),

(v) Fax messaging,

(vi) International Telephony,

(vii) Downloading free soft ware for your personal computer,

(viii) Radio-programme,

(ix) On-line job opportunities,

(x) Order books, journals and magazines,

(xi) Borrow books and materials on-line from libraries world wide. 


\section{What are the potential benefits of using Internet?}

The internet offers wide range of services which include;

- acts as a medium for electronic communication among students, teachers, administrators, mangers, researchers and experts in all kinds of profession,

- Provides access to electronic sources of information through facilities like WWW, FTP and Tel net.

- Improve administration and management through email and discussion group facilities.

- Remove some of the spatial and temporal constraints of communication and community building by providing electronic access to people and resources.

- Facilitate equity by removing barriers to publication of ideas and information.

- Facilitate learning and equity by empowering people through access to large amounts of information, to real-time information electronic resources and remote sides.

- Means of advertising organization products and services.

\section{Internet and Obafemi Awolowo University Experience}

The Obafemi Awolowo University Network (O.A.U Net) started around 1996 as a result of collaborated effort between Obafemi Awolowo University and International Centre for Theoretical Physics (ICTP) Trieste, Italy. Under this agreement the ICTP is to provide access to international information networks that will promote science and technology within the University Community and to Nigeria. Under the project, a University Computer Network (OAUNET) was established with Internet connectivity. Initially it was 
established on wave LAN with mail host and Router located at the Computer Centre. It was also linked to Internet through ICTP computer network in Trieste. The operating system was based on LINUX, TCP/IP and radio wave. Today OAU NET has been upgraded from the initial 3 subnets to 14 subnets. There is VSAT Internet connectivity operating in the band with. The existing VSAT and other supporting hardware have been upgraded to a minimum band with of 256 to $512 \mathrm{Kbps}$. Not only this, the University started the introduction of fiber optic based technology instead of the current slow speed wire less radio wave system. Not only this, effort was also made to connect the University to satellite. Through this agreement and effort by the management of O.A.U. Ile-Ife, the University was linked to the World Wide Web.

\section{The Vision for Establishing the Obafemi Awolowo University NET}

According to Ajayi (1996) parts of the objectives for the OAUNET are:

(i) speedy, inexpensive and convenient means of communication,

(ii) gathering, storage and dissemination of vital information for regional and national collaborative research,

(iii) administrative purposes,

(iv) facilitate on-line library services, and

(v) computer -aided distant lecturing and tutoring

Kehinde (2003) in a lecture delivered on "OAUNET Backbone for Open and Distance Education" identified what the strategic goals for OAU Net . They include: 
- to make the entire community (Staff / Student) computer literate and have proficiency in Information and Communication Technology (ICT),

- to develop ICT to the highest level and to enable it serves as the backbone of OAU,

- set aside an appropriate fund to support ICT, encourage all staff and students to have access and use the internet,

- establish an ICT centre (at the rate of 1 PC per 50 students), and

- computerize and make library services and facilities remotely available to all staff and students through a special site on the University intra-web.

Apart from the above a high level committee was set up by the University administration to advice the University on the possibilities of multi site learning. The committee members have since swung into action. Two Departments, the INTECU / Computer unit and the Department of Educational Technology are at the centre. As part of the move to ensure the success of integrating ICT to solve the numerous problems facing teaching, research, management and administration, several workshops, and training the trainers both for the academics and non academic staff have been organized. Prior to this period, computation of student's results and other vital information are being done manually. With the integration of ICT, examination and computation of results have been automated. Registrations for courses are done on-line. The Hezekiah Oluwasanmi Library is not left out of this innovation, through the assistance of the Carnegie Corporation, the library have made available current, relevant library facilities and foreign journals through a special University intra-web facilities. There are still lots of problems facing this innovation. It involves how to encourage more 
students and staff of O.A.U. Ile-Ife to use ICT to solve work place problems and that of examination results, research, teaching, administration and management. It also has to do with changing the attitude of both the staff and the students to the effort at integrating ICT into the University.

\section{Procedure}

The researcher employed a survey research design.

\section{Population}

The population for the study is made up of all the O.A.U Staff in Ile-Ife.

\section{Sample}

A sample of 600 staff of O.A.U Ile-Ife was selected through stratified sampling technique. The criteria for selection were based on; profession, age, cadre and gender. The breakdown is as follows

(i) Academic Staff - 300

(ii) non academic staff 300

\section{Instrument}

The instrument used for the study is made up of structured questionnaire designed in parts. The instrument was adapted from Jay and Willis (1992). It is multidimensional measure that assess attitude towards computer. The first section deals with demographic data while section II was concerned with experience and competence in computer, access to Internet services and duration of patronage. Section III is concerned with attitude towards computer and Internet. 


\section{Validation of Instrument}

Although several studies have tested the reliability and validity of the instrument (Zoltan and Chapanis 1982, Krauss and Hoyer, 1984, Nickell \& Pinto 1984, Dambrot et-al 1985, Elkins, 1985, Richards, Johnson and Johnson 1986, Bear, Richards and Lancasters 1987), the researcher still consulted expert judgment to ascertain its construct judgement. The experts are from Tests and Measurement, Educational Technology and Psychology.

\section{Limitations}

Out of the 600 questionnaires distributed to the staff only 495 were returned academic staff 231 while 224 for the non-academic staff. Forty of the participants also did not complete the questionnaire.

\section{Result and findings}

\section{Below are the results of the data analyzed.}

Table1: Do you use computer?

\begin{tabular}{||l|l|l|l||}
\hline Yes & 463 & 94 & 94.7 \\
No & 25 & 5.1 & \\
Missing & 6 & 1.2 & \\
\hline Total & 495 & 100 & \\
\hline
\end{tabular}

Ninety five percent of the O.A.U. staff agreed that they use computer, while $5 \%$ of the respondents sampled do not use computer. Further probing question were asked on why they do not use computer. Find below the findings in table II. 
Table II: Why don't you use computer?

\begin{tabular}{||l|l|l|l|l||}
\hline \multirow{2}{*}{ I Don't Need Them } & Frequency & $\mathbf{\%}$ & $\begin{array}{l}\text { Valid } \\
\mathbf{\%}\end{array}$ & $\begin{array}{l}\text { Cumulative } \\
\mathbf{\%}\end{array}$ \\
\cline { 2 - 5 } Too Expensive & 10 & 2.00 & 27.8 & 27.8 \\
$\begin{array}{l}\text { Not Available } \\
\text { I Don't Know How To } \\
\text { Use It }\end{array}$ & 11 & 0.8 & 11.1 & 38.9 \\
Missing System & 11 & 2.2 & 30.6 & 69.4 \\
\hline Total & 459 & 2.2 & 30.6 & 100 \\
\hline
\end{tabular}

The reasons why they had not been using computer include, those who don't know how to $30.6 \%$, too expensive $0.8 \%$, and those who belief they do not need it $2 \%$. On the duration of usage, the following are the results obtained.

Table III: Since when have you been using computer

\begin{tabular}{||l|l|l|l|l||}
\hline \hline & Frequency & Percent & Valid \% & $\begin{array}{l}\text { Cumulative } \\
\text { \% }\end{array}$ \\
\cline { 2 - 5 } & & 18.6 & 20.4 & 20.4 \\
Under 1 year & 92 & 57.4 & 62.8 & 83.2 \\
Under10 years & 284 & 13.1 & 14.4 & 97.6 \\
$10-15$ years & 6 & 1.2 & 1.3 & 98.9 \\
Over 15 years & 4 & 0.8 & 0.9 & 99.8 \\
21.00 & 1 & 0.2 & 0.2 & 100.0 \\
Missing system & 43 & 8.7 & & \\
\hline Total & $\mathbf{4 9 5}$ & $\mathbf{1 0 0}$ & & \\
\hline
\end{tabular}

$18.6 \%$ of the respondents had used computer for only 1 year, $57.4 \%$ between 1 to 5 years, $13.1 \%$ under 10 years and $1.2 \%$ between $10-15$ years. While only $0.8 \%$ had used it for over 15 years. On the issue of gender in computer usage, the result of the data collected showed that there are more 
female (53.9 percent) that uses computer than the male (39.6 percent, see table IV).

Table IV Sex distribution of computer usage

\begin{tabular}{||l|l|l|l|l||}
\hline \hline & Frequency & Percent & Valid \% & $\begin{array}{l}\text { Cumulative } \\
\text { \% }\end{array}$ \\
\cline { 2 - 5 } & & & & \\
Male & 196 & 39.6 & 42.3 & 42.3 \\
Female & 267 & 53.9 & 57.7 & 100 \\
Missing System & 32 & 6.5 & & \\
\hline Total & $\mathbf{4 9 5}$ & $\mathbf{1 0 0}$ & & \\
\hline
\end{tabular}

The researcher asked further probing question from these categories of staff that made use of computer. Find below the findings in table $\mathrm{V}$

Table V: Designation of those who use computer

\begin{tabular}{||l|l|l|l|l||}
\hline \hline & Frequency & Percent & $\begin{array}{l}\text { Valid } \\
\text { \% }\end{array}$ & $\begin{array}{l}\text { Cumulative } \\
\text { \% }\end{array}$ \\
\cline { 2 - 5 } Academic Staff & 224 & 45.3 & 49.2 & 49.2 \\
Technical Staff & 27 & 5.5 & 5.9 & 55.2 \\
Administrative & 110 & 22.2 & 24.2 & 79.3 \\
Secretariat & 94 & 19.0 & 20.7 & \\
Staff & 40 & 8.1 & & \\
Missing & 495 & & & \\
\hline Total & $\mathbf{1 0 0}$ & & \\
\hline
\end{tabular}

From the data collected, the academic staff (45.3\%) used the computer more than other categories of staff. This was closely followed by administrative staff (22.2\%), secretariat staff $(19.0 \%)$, and lastly the technical staff $(5.5 \%)$. With regards to computer skill, the staff were asked to indicate their level of computer skill, below is the result obtained. 
Table VI: Staff computer skills

\begin{tabular}{||l|l|l|l|l||}
\hline \hline & Frequency & Percent & $\begin{array}{l}\text { Valid } \\
\text { \% }\end{array}$ & $\begin{array}{l}\text { Cumulative } \\
\%\end{array}$ \\
\cline { 2 - 5 } No Problem & 271 & 54.7 & 57.7 & 57.7 \\
Average & 131 & 26.5 & 27.9 & 85.5 \\
Problematic & 51 & 10.3 & 10.9 & 96.4 \\
Very Problematic & 17 & 3.4 & 3.6 & \\
Missing System & 25 & 51 & & \\
\hline Total & $\mathbf{4 9 5}$ & $\mathbf{1 0 0}$ & & \\
\hline
\end{tabular}

Fifty four percent of the staff was computer literate. They were of the opinion that they had no problem using computer. While $27.9 \%$ opined that they can fairly use computer. $10.3 \%$ find it problematic and $3.4 \%$ very problematic to use computer. From the information collected on what the staff use computer for find the result below.

Table VII: What do you use computer for?

\begin{tabular}{||l|l|l|l|l||}
\hline \hline \multirow{3}{*}{$\begin{array}{l}\text { Staff } \\
\text { Category }\end{array}$} & & & & \\
& & & & \\
\cline { 2 - 5 } & e-mail & $\begin{array}{l}\text { Word } \\
\text { processing }\end{array}$ & News & Entertainment \\
\hline Academics & 167 & 21 & 2 & 10 \\
Technical & 18 & 7 & 5 & 15 \\
Administrative & 58 & 33 & 1 & 11 \\
Secretariat & 36 & 41 & 3 & 3 \\
\hline
\end{tabular}

The result obtained showed that $77 \%$ of the academic staff used computer and internet for e-mail and research; this was followed by administrative staff $60.4 \%$ for word processing. In order to determine whether the data obtained 
was not by chance, it was subjected to chi-square statistic, find below the data obtained (see table (VIII).

Table VIII Chi-square test

\begin{tabular}{|l|l|l|l||}
\hline & Value & df & Asymp. Sig \\
\hline $\begin{array}{l}\text { Pearson chi-square } \\
\text { Likelihood Ratio } \\
\text { Linear by linear } \\
\text { association }\end{array}$ & 59.557 & 9 & .000 \\
\hline
\end{tabular}

When the different scores of the various categories of staff were compared, a chi-square value of 59.56 was obtained. This showed that there was a significant relationship between designation and what the respondents use computer and internet for. With regards to the University efforts at encouraging the use of computer and ICT, 78.2\% said they were favorably disposed to it, $4.8 \%$ were not favorably disposed and $5.1 \%$ remained indifferent. Find below the findings in tables IX and $X$.

Table IX: Staff Disposition to the Use of Internet and Computer

\begin{tabular}{|c|c|c|c|c|c|}
\hline & & $\begin{array}{l}\text { Frequ } \\
\text { ency }\end{array}$ & $\%$ & $\begin{array}{l}\text { Valid } \\
\%\end{array}$ & $\begin{array}{l}\text { Cum } \\
\%\end{array}$ \\
\hline $\begin{array}{l}1 \text { am-------- } \\
\text { to the } \\
\text { University } \\
\text { policy and } \\
\text { effort at } \\
\text { encouraging } \\
\text { the Use of } \\
\text { computer \& } \\
\text { Internet } \\
\end{array}$ & $\begin{array}{l}\text { Favorably disposed } \\
\text { Not Favorably disposed } \\
\text { Indifference } \\
\text { missing }\end{array}$ & $\begin{array}{l}387 \\
24 \\
25 \\
59\end{array}$ & $\begin{array}{l}78.2 \\
4.8 \\
5.1 \\
11.9\end{array}$ & $\begin{array}{l}88.8 \\
5.5 \\
5.7 \\
100.0\end{array}$ & $\begin{array}{l}88.8 \\
94.3 \\
100.0\end{array}$ \\
\hline \begin{tabular}{|l} 
Total \\
\end{tabular} & & 495 & 100 & & \\
\hline
\end{tabular}


Table X: Are you in support that all cadres of staff should acquire computer skills?

\begin{tabular}{||l|l|l|l|l||}
\hline \hline & Frequency & \% & Valid \% & Cumulative \% \\
\hline Yes & 432 & 87.3 & 92.7 & 92.7 \\
No & 34 & 6.9 & 7.3 & 100 \\
Missing & 29 & 5.9 & 100.0 & \\
\hline Total & $\mathbf{4 9 5}$ & $\mathbf{1 0 0 . 0}$ & & \\
\hline
\end{tabular}

On the various training programmes and the workshop organized by the university at encouraging the staff to appreciate computer, $94.1 \%$ of the sample said it enhanced their interest and attitude towards computer, while 36 said it had no effect on them (see table XI)

Table XI Does the EDP Training and Various Workshops you attended Enhance Your Attitude/Performance

\begin{tabular}{||l|l|l|l|l||}
\hline \hline & Frequency & $\mathbf{\%}$ & Valid \% & Commutative \% \\
\hline Yes & 466 & 94.1 & 96.3 & 96.3 \\
No & 18 & 3.6 & 3.7 & 100 \\
Missing & 11 & 2.2 & & \\
\hline Total & $\mathbf{4 9 5}$ & $\mathbf{1 0 0}$ & & \\
\hline
\end{tabular}

In order to find out whether age has anything to do with staff disposition to using computer, find below the result obtained (see tables XII and XIII). 
Table XII: Age as a correlate of computer usage

\begin{tabular}{|l|l|l|l||}
\hline $\begin{array}{l}\text { Age Bracket } \\
\text { of the } \\
\text { Respondents }\end{array}$ & $\begin{array}{l}\text { Staff between ages 25 \& 40 are } \\
\text { usually more favorably disposed } \\
\text { to use ICT than the staff Who are } \\
\text { above 40 years }\end{array}$ & \multicolumn{2}{|l|}{ TOTAL } \\
\hline & Yes & No & \\
\hline Below 25 years & 4 & 4 & 8 \\
$25-30$ years & 106 & 3 & 109 \\
$30-40$ Years & 185 & 15 & 200 \\
$40-50$ years & 126 & 16 & 142 \\
50 above & 27 & 9 & 36 \\
\hline Total & $\mathbf{4 4 8}$ & $\mathbf{4 7}$ & $\mathbf{4 9 5}$ \\
\hline
\end{tabular}

Table XIII chi-square test of age \& computer usage

\begin{tabular}{|l|l|l|l|}
\hline & Value & df & $\begin{array}{l}\text { Asymp. } \\
\text { Sign }\end{array}$ \\
\hline $\begin{array}{l}\text { Pearson chi-square } \\
\begin{array}{l}\text { Likelihood Ratio } \\
\text { Linear by linear } \\
\text { association }\end{array}\end{array}$ & 15.672 & 4 & .003 \\
\hline No of valid cases & 6.370 & 1 & .003 \\
\hline
\end{tabular}

From table XIII, the result obtained showed that age is a determinant of computer usage. Staffs that are below 50 years are generally more enthusiastic and favorably disposed to computer than staff that are above 50 years. The chisquare obtained was 15.67 .

In order to improve the skill of the staff in computer and internet usage further questions were asked on whether they will want further training, $89.5 \%$ of the respondents said yes, while $3.2 \%$ said no and $1.0 \%$ were indifferent see tables XIV\& XV 
Table XIV: Will you like to receive more training to enhance your computer skill

\begin{tabular}{|l|l|l|l|l|}
\hline & Frequency & \% & Valid \% & Cumulative \\
\hline Very interested & 443 & 89.5 & 95.5 & 95.5 \\
Less interested & 13 & 2.6 & 2.8 & 98.3 \\
Uninterested & 3 & 0.6 & 0.6 & 98.9 \\
Indifferent & 5 & 1.0 & 1.1 & 100.0 \\
Missing & 31 & 6.3 & & \\
\hline Total & $\mathbf{4 9 5}$ & $\mathbf{1 0 0 . 0}$ & & \\
\hline
\end{tabular}

Table XV Will you like to receive more training to enhance your internet skills

\begin{tabular}{|l|l|l|l|l|}
\hline & Frequency & \% & Valid \% & Cumulative \\
\hline Yes & 465 & 93.9 & 96.9 & 96.9 \\
No & 15 & 3.0 & 3.1 & 100.0 \\
Missing & 15 & 3.0 & & \\
\hline Total & $\mathbf{4 9 5}$ & $\mathbf{1 0 0 . 0}$ & & \\
\hline
\end{tabular}

From tables XIV and XV it was observed that $89.5 \%$ would like to go for more training in computer while $93.5 \%$ would want more training in the use of internet. This is sequel to the information requested from the respondents on how long it took them to compose, read and send e-mail messages. Forty six percent of the sample spent less than I hour, 30.5\% between 1.2 hours, 11.1 between 2 and 4 hours. With regards to the frequency of usage, $51 \%$ use internet daily, $21 \%$ weekly $4 \%$ monthly $11.5 \%$ seldom and $8.1 \%$ do not use the internet at all (See tables XVI \& XVII) 
Table XVI: Frequency of utilizing Internet

\begin{tabular}{|l|l|l|l|l|}
\hline & Frequency & \% & Valid \% & Cumulative \\
\hline Daily & 252 & 50.9 & 53.7 & 53.7 \\
Weekly & 102 & 20.6 & 21.7 & 75.5 \\
Monthly & 20 & 40 & 4.3 & 79.7 \\
Seldom & 57 & 11.5 & 12.2 & 91.9 \\
Not applicable & 38 & 7.7 & 8.1 & 100.0 \\
Missing & 26 & 5.3 & & \\
\hline Total & $\mathbf{4 9 5}$ & $\mathbf{1 0 0 . 0}$ & & \\
\hline
\end{tabular}

Table XVII: How long does it take you to compose read and send e-mail message?

\begin{tabular}{|l|l|l|l|l|}
\hline & Frequency & $\mathbf{\%}$ & Valid \% & $\begin{array}{l}\text { Cumulative } \\
\text { \% }\end{array}$ \\
\hline Less than 1 hour & 227 & 45.9 & 51.8 & 51.8 \\
$1-2$ hours & 151 & 30.5 & 34.5 & 86.3 \\
$2-4$ hours & 55 & 11.1 & 12.6 & 98.9 \\
$4-6$ hours & 2 & 0.4 & 0.5 & 99.3 \\
Over 6 hours & 2 & 0.4 & 0.5 & 99.8 \\
Missing & 57 & 11.5 & & \\
\hline Total & $\mathbf{4 9 5}$ & $\mathbf{1 0 0 . 0}$ & & \\
\hline
\end{tabular}

The above question items were asked in order to determine the literacy level of the respondents with regards to the utilization of internet. Although the findings revealed that $40.2 \%$ of the respondents had problem with the required internet skills. Other reasons giving include the speed of connection and incessant power outage (see tables XVI \& XVII). 
Table XVIII: Constraints to utilizing internet (Speed of connection).

\begin{tabular}{|l|l|l|l|l|}
\hline & Frequency & \% & Valid \% & Cumulative \% \\
\hline No problem at all & 07 & 21.6 & 23.8 & 23.8 \\
Average & 100 & 20.2 & 22.3 & 46.1 \\
Problematic & 108 & 21.8 & 24.1 & 70.2 \\
Very problematic & 180 & 36.4 & 29.8 & 100.0 \\
\hline Total & $\mathbf{4 9 5}$ & $\mathbf{1 0 0 . 0}$ & & \\
\hline
\end{tabular}

From the above $58.2 \%$ of the respondents said the speed of connection is slow and problematic. This finding has implication on the integration of ICT into O.A.U Ile-Ife. The incessant power outages, slow speed of connection and constant problem with the Internet sever must be addressed. If this is not addressed when the University completely goes on-line, there may be serious problems. Perhaps it may be this that had affected the attitude of the staff to showing negative attitude to computer and internet (see table XVII)

Table XIX: Are you interested in using the facilities provided

\begin{tabular}{|l|l|l|l|l|}
\hline & Frequency & $\mathbf{\%}$ & Valid \% & $\begin{array}{l}\text { Cumulative } \\
\text { \% }\end{array}$ \\
\hline Yes & 289 & 58.4 & 66.1 & 66.1 \\
No & 206 & 41.6 & 33.9 & 100.0 \\
\hline Total & $\mathbf{4 9 5}$ & $\mathbf{1 0 0 . 0}$ & & \\
\hline
\end{tabular}

Table XX: Level of satisfaction with the Internet facilities

\begin{tabular}{|l|l|l|l|l|}
\hline & Frequency & $\mathbf{\%}$ & Valid \% & $\begin{array}{l}\text { Cumulative } \\
\text { \% }\end{array}$ \\
\hline Very satisfied & 216 & 43.6 & 47.7 & 47.7 \\
Satisfied & 137 & 27.7 & 30.2 & 77.9 \\
Averagely & 59 & 11.9 & 13.0 & 90.9 \\
satisfied & 32 & 6.5 & 7.1 & 98.0 \\
Unsatisfied & 51 & 10.3 & 2.0 & 100.0 \\
Very satisfied & & & & \\
\hline Total & $\mathbf{4 9 5}$ & $\mathbf{1 0 0 . 0}$ & & \\
\hline
\end{tabular}




\section{Implication of the Findings}

The findings from this study have some implications for the development, integration and utilization of ICT at O.A.U Ile-Ife. They include the need to encourage more staff especially the older and more experienced one to appreciate and use ICT. The need to improve the Internet facilities, encourage more non academic staff and the clerical staff cadre to using ICT. Although the focus of this paper is not on the students but events have showed that more awareness programme would have to be carried out if the students are to benefit from the ICT programme. Not only this, more computers will have to be purchased., more cyber café will have to be established if the University is to completely go on-line and is to fulfill the objective of $1 \mathrm{pc}$ per 50 students. Also apart from the compulsory policy of the University that all cadres of staff be computer literate, other ways of motivating this staff be looked into. There had been problems with this policy; workers attend the course just to obtain the certificate because it is needed for promotion without developing positive interest in ICT.The workers are not self motivated but forced because without a certificate of attendance they will not move to the next level.

\section{Conclusion}

The following were the conclusion drawn from the study.

(i) $94 \%$ of the staff O.A.U used computer

(ii) The academic staff used computer and internet more than other categories of staff.

(iii) Female staff (58\%) used ICT more than their male staff (42\%).

(iv) Age is a correlate of ICT usage. 
(v) $87.3 \%$ of the staff is positively disposed to the University policy that every staff should acquire ICT skills.

(vi) Many of the university staff are not self motivated to acquire ICT skills but they attend the training because it is compulsory, without which they could not progress to the next level.

\section{References}

Adler, R (2002) The Age Weave meets the technology wave: Broad band and the older Americans. Pale Alte; CA; Senior Net

Ajayi, G.O. (1996) Obafemi Awolowo University ICTP Academic Computer Network Project (O.A.U Net): Users Guide Version 1.0.

Bear, G.G, Richard, H.C and Lancasters, M (1987) Attitude Towards Computers: Validation of a Computer Attitude Scale. Journal of Educational Computing \& Research 3 207-218.

China Daily News (2004) Elderly Surfers Click Onto Net. Retrieved January S, 2004.

Czaja, S.J. and Sharit, J (1998): Age difference in Attitudes Towards Computer. Journal of Gerontology: 53 (5), 329-340.

Dambrot, F.H Watkins. Malek, M.A., Silling S.M

Marshall, R.S. and Garver, J. (1985). Correlates of Sex differences in Attitudes towards and involvement with computer. Journal of Behaviour 27 71-86

Elkins, R. (1985) Attitude of special (Education Personnel Towards Computer). Educational Technology 25 (7) 31 34. 
Jay. G.M and Willis, S.I (1992) Influence of Direct Computers Experience on Older Adults Attitude Towards Computer Journal of Gerontology 47 (4), 250-257

Kelly, C.L, Morell, R.W Park, DC and Magherm, C.B. (1999) Predictors of Elections Bulletin Board System use in older Adults Educational Gerontology 25 (1). 19-35

Kerschiner, P.A. and Chels Vig-Hart, K (1984) The Aged User and Technology. In R.E Dunkle, M.R.Haug. And M. Rosenberg (Eds).Communications Technology and the Elderly Issues and Forecasts (pp 135 - 144) New York: Springer

Kraus, I.K and Hoyer, W.H. (1984) Technology and the Older Person: Age Sex and Experience as Moderates of Attitude toward Computers. In P.K. Robinson, J. Livingston and J.E Birren (Eds) Aging and Technological Advances (pp 349 - 350) New York: Plenum.

Morell, R.W., Mayhorn, C.B. and Benneth R.I (2002) A Survey at World Wide Use in Middle Aged and Older Adults Human Factors 42 (2), 175-182.

Morris, D and Deollos. I (2004) Journal of Educational Technology Systems 32 (3)

Nickel, G.S and Pinto, J.N (1984) The Computer Attitude Scale (CAS). Paper Presented at the Annual Meeting of the South Western Psychological Association New or Leans LA.

Renee, A.B. (1997) Training Older Adults to use the Computer: Issues Related to the workplace, Attitude and Training Educational Gerontology 23 (5) 403 466.

Richards P.S. Johnson, D.W. and Johnson R.T. (1986). A Scale for Assessing Students Attitude Towards 
Computer. Preliminary Findings. Computers in the Schools 3 92) 31-38.

Senior Net (2002a) Senior Net Survey on Internet Use Palo Alto.

Senior Net (2002b) Exploring Internet Use Among Older Adults. Parlo Alto.

White, H,. Mclonnell, E, Clipp E, Branch, L.G. Sloamme R, Peper, C and Box T.L (2002).

A randomized controlled Trial of the Psychological Impact of Providing Internet Training and Access to Older Adults. Ageing and Mental Health 6(3), 213-221

Zoltan, E, and Chapanis, A (1982). What do Professionals Think about Computer. Behaviour and Information Technology 1, 55-68 